\title{
PENYULUHAN PENGGUNAAN BAHAN BAKAR GAS UNTUK BECAK MOTOR DI JL. CIPTA KARYA KELURAHAN SIANGLA MUNGGU KECAMATAN TAMPAN
}

\author{
Jusnita*, Indra Hasan, Denur \\ Program Studi Mesin Otomotif, Fakultas Teknik \\ *email: jusnita@umri.ac.id
}

\begin{abstract}
Abstrak
Kehadiran becak motor ditengah banyaknya permasalahan transportasi masyarakat, seakan menjawab kebutuhan sarana transportasi yang representative. Tujuan pelaksanaan kegiatan ini adalah membantu masyarakat dalam mengatasi krisis BBM dengan cara penyuluhan penggunaan BBG LPG $3 \mathrm{~kg}$ pada becak motor. Metode yang digunakan adalah ceramah, Tanya jawab, diskusi, demonstrasi. Manfaat kegiatan ini adalah; a) Memberikan Ipteks bagi masyarakat. b) Membantu masyarakat dalam krisis BBM. Kegiatan penyuluhan penggunaan BBG LPG $3 \mathrm{Kg}$ pada becak motor dilaksanakan di Kelurahan Siangla Munggu Kecamatan Tampan pada hari Minggu tanggal 05 Januari 2017 dan kegiatan ini dimulai pukul 08. ${ }^{00}$ wib sampai dengan pukul $16 .^{00}$ wib. Di awali dengan mengumpulkan peserta disalah satu rumah warga, sekaligus sebagai tempat pelatihan. Hasil kegiatan pengabdian masyarakat secara garis besar mencakup beberapa komponen sebagai berikut; 1). Keberhasilan target jumlah peserta penyuluhan 2) Ketercapaian tujuan pelatihan 3) Ketercapaian target materi yang telah direncanakan 4). Kemampuan peserta dalam penguasaan materi. Peserta penyuluhan 10 orang yang berprofesi sebagai becak motor. Dengan demikian dapat dikatakan bahwa target peserta tercapai 100\%. Angka tersebut menunjukkan bahwa kegiatan pengabdian masyarakat dilihat dari jumlah peserta yang ikut dapat dikatakan berhasil. Luaran yang dicapai dalam pengabdian ini adalah media cetak yang sudah diterbitkan di tribun dan jurnal.
\end{abstract}

Kata kunci : Bahan bakar minyak, Penyuluhan, bahan bakar gas LPG, becak motor

\section{PENDAHULUAN}

Berdasarkan data kependudukan dari kantor kelurahan Siangla Munggu pada bulan Januari 2014, jumlah penduduk Kelurahan Siangla Munggu Kecamatan Tampan tercatat 19.057 jiwa. Dari 19.050 jiwa tersebut terdiri dari laki-laki 9.915 jiwa dan perempuan 9.142 jiwa. Adapun jumlah RT dan RW di Kelurahan Siangla Munggu Kecamatan Tampan adalah terdiri dari 44 RT, 11 RW Dan 4 Dusun. Sedangkan jumlah kepala keluarga yang tercatat januari 2014 adalah 4.974 Kepala Keluarga (KK).

Sejak terjadinya krisis ekonomi di Indonesia pada tahun 1998 banyak sekali kegiatan ekonomi yang cenderung beralih pada sektor informal. Terlebih selama krisis moneter menyebabkan banyak industri gulung tikar, sehingga banyak terjadi pemutusan hubungan kerja. Hal ini pada gilirannya menambah penggangguran baru, yang nantinya muncul fenomena fenomena baru. Salah satu sektor yang kini menjadi perhatian pemerintah adalah KecamatanTampan khususnya di kelurahan Siangla Munggu adalah sektor tenaga kerja yang sifatnya informal.

Becak Motor merupakan angkutan sepeda motor yang 
dimodifikasi dengan menambah bagian samping untuk muatan penumpang sebanyak dua orang. Awal mula tahun 1998 becak motor di Kelurahan Siangla Munggu hanya berjumlah 24 becak motor dan becak motor sangat diminati oleh masyarakat. Hal ini di karenakan becak motor dapat membantu mobilitas masyarakat kelurahan Siangla Munggu, salah satunya dalam berbelanja di Pasar, mengantar anak-anak ke sekolah dan lain sebagainya. Kehadiran becak motor ditengah banyaknya permasalahan transportasi masyarakat yang naik kepermukaan, dan ini ( becak motor ) seakan menjawab kebutuhan sarana transportasi yang representative, karena kelincahan dan kepraktisan dalam menyusuri jalan-jalan kecil dan sempit yang tidak dilalui oleh angkutan umum, dan juga praktis karena dapat membawa barang dalam jumlah yang cukup banyak serta selalu siap sedia setiap saat.

\section{METODE PENGABDIAN}

Metode yang digunakan dalam pengabdian ini adalah metode pendekatan ditingkat RT untuk mensinergikan kegiatan-kegiatan dalam program khususnya yang berkaitan dengan permasalahan krisis bahan bakar. Solusi yang di tawarkan adalah Penyuluhan Penggunaan Bahan Bakar Gas Pada Becak motor. Metode pendekatan yang ditawarkan untuk mendukung realisasi program penyuluhan penggunaan bahan bakar gas melalui pendekatan proses ceramah, demonstrasi dan praktek langsung. Instruktur kegiatan berasal dari Dosen Mesin Otomotif Fakultas Teknik UMRI dibantu oleh mahasiswa Program Studi Mesin Otomotif UMRI.

Materi pelatihan ini meliputi tentang perakitan penggunaan bahan bakar gas pada becak motor ditambah dengan materi perawatan dari becak motor tersebut. Materi kompetensi dasar yang diberikan bertujuan membentuk skill peserta penyuluhan agar mampu menangani kerusakan pada Becak motor. Total waktu pelaksanaan kegiatan ini adalah selama 3 hari.

\section{HASIL DAN PEMBAHASAN}

Penyuluhan penggunaan bahan bakar gas untuk becak motor yang dilaksanakan di Jalan Cipta Karya Kelurahan Siangla Munggu Kecamatan Tampan pada hari Minggu tanggal 05 Januari 2017 dan kegiatan ini dimulai pukul 08.00 wib sampai dengan pukul 16.00 wib. Kegiatan ini diawali dengan mengumpulkan peserta disalah satu rumah penduduk yang sekaligus sebagai tempat pelatihan. Target peserta 10 orang yang mempunyai becak motor. Acara selanjutnya adalah penyuluhan penggunaan bahan bakar gas oleh dosen dibantu oleh mahasiswa Program Studi Mesin Otomotif Fakultas Teknik UMRI dalam menyampaikan hal-hal yang berkaitan dengan cara penggunaan bahan bakar gas melalui metode praktek pada becak motor. Peserta terlihat antusias mengikuti kegiatan ini, dan mereka sangat tertarik untuk mencoba pada becak motor. Setiap peserta disarankan untuk mempraktekkan langsung pada becak motor mereka masingmasing. Hasil kegiatan pengabdian masyarakat secara garis besar mencakup beberapa komponen sebagai berikut; 1) Keberhasilan 
target jumlah peserta pelatihan 2) Ketercapaian tujuan pelatihan 3) Ketercapaian target materi yang telah direncanakan 4) Kemampuan peserta dalam penguasaan materi. Target peserta penyuluhan seperti direncanakan sebelumnya 10 orang yang berprofesi sebagai becak motor. Dalam pelaksanaannya, kegiatan ini diikuti oleh 10 orang peserta. Dengan demikian dapat dikatakan bahwa target peserta tercapai $100 \%$. Angka tersebut menunjukkan bahwa kegiatan pengabdian masyarakat dilihat dari jumlah peserta yang mengikuti dapat dikatakan berhasil/ sukses. Ketercapaian tujuan pengabdian masyarakat secara umum sedah baik, namun keterbatasan waktu yang disediakan mengakibatkan tidak semua materi tentang penggunaan bahan bakar gas dapat disampaikan secara detil. Namun dilihat dari hasil latihan para peserta yaitu kualitas media penyuluhan yang telah dihasilkan, maka dapat disimpulkan bahwa tujuan kegiatan ini dapat tercapai.

Ketercapaian target materi pada kegiatan PPM ini cukup baik, karena materi penyuluhan telah dapat disampaikan secara keseluruhan. Materi pendampingan yang telah disampaikan adalah :

1. Teori pengenalan alat dan penggunaannya, keselamatan kerja

2. Teori Dasar-dasar dari sepeda motor

3. Sosialisasi Kendaraan Berbahan Bakar Gas

4. Praktek Pemasangan Bahan Bakar Gas Pada Kendaraan

Kemampuan peserta dilihat dari penguasaan materi masih kurang dikarenakan waktu yang singkat dalam penyampaian materi dan kemampuan para peserta yang berbeda-beda. Hal ini disebabkan jumlah materi yang banyak hanya disampaikan dalam waktu sehari sehingga tidak cukup waktu bagi para peserta untuk memahami dan mempraktekkan secara lengkap semua materi yang diberikan. Secara keseluruhan kegiatan pengabdian masyarakat tentang penyuluhan penggunaan bahan bakar gas untuk becak motor ini dapat dikatakan berhasil. Keberhasilan ini selain diukur dari keempat komponen di atas, juga dapat dilihat dari kepuasan peserta setelah mengikuti kegiatan. Manfaat yang diperoleh masyarakat yang berprofesi sebagai becak motor adalah dapat mengatasi krisis dari bahan bakar minyak dan dengan menggunakan bahan bakar gas yang mempunyai kualitas yang lebih baik.

\section{KESIMPULAN}

Kesimpulan yang dapat diambil dari kegiatan pengabdian masyarakat ini adalah :

1. Dapat mengatasi krisis bahan bakar yang terjadi pada masyarakat.

2. Sebagai implementasi dari penelitian

3. Sebagai ajang promosi bagi Program Studi Mesin Otomotif Fakultas Teknik UMRI

\section{UCAPAN TERIMA KASIH}

Ucapan terima kasih atas pelaksanaan dari kegiatan pengabdian masyarakat kepada :
1. Rektor
Universitas
Muhammadiya Riau yang telah menfasilitasi
kegiatanpengabdian masyarakat ini.
2. Ketua LPPM UMRI yang telah mengagendakan kegiatan pengabdian masyarakat dikalangan dosen UMRI 
3. Dekan Fakultas Teknik UMRI yang telah member dukungan atas pelaksanaan pengabdian masyarakat ini.

4. Ketua Program Studi Mesin Otomotif yang telah memotifasi kegiatan pengabdian ini.

5. Semua dosen dan mahasiswa Program Studi Mesin otomotif yang terlibat dalam agenda pengabdian masyarakat ini.

\section{DAFTAR PUSTAKA}

[1] Arijanto, dkk, Penggunaan Gas Sebagai Bahan Bakar Sepeda Motor Injeksi, 2015

[2] Atok Setiayawan, Teknologi Konversi Energi Bensin Ke Bahan Bakar Gas. 2012

[3] BPH Migas, Perbandingan udara dan bahan bakar dalam bentuk volume pada pemakaian bahan bakar gas, 2007

[4] Achmad Fauzan HS, disain converter kits modifikasi sistem bahan bakar motor bensin menjadi berbahan bakar gas, 2007

[5] Hadi Purnomo, Badan Pengkajian dan Penerpan Teknologi, 2006

[6] Tulus BS. Jurnal Teknik Mesin ITB; Harmen 2002

[7] Tulus BS. Jurnal Teknik Mesin ITB; Harmen 2001

[8] Hammond Fred, dkk, Jurnal Saint dan Teknologi. BPPT, April 3, 1996,. V6-04 